DOI: https://doi.org/10.24127/ajpm.v9i1.2617

\title{
KEMAMPUAN BERPIKIR KRITIS MATEMATIS MENGGUNAKAN MODEL GENERATIVE LEARNING DAN CONNECTING, ORGANIZING, REFLECTING, EXTENDING (CORE)
}

\author{
Agustiani Putri $^{1}$, Dadan Sumardani ${ }^{2}$, Wardani Rahayu ${ }^{3}$, Mimi Nur Hajizah ${ }^{4}$ \\ ${ }^{1,2,3,4}$ Pendidikan Matematika, Universitas Negeri Jakarta, Indonesia \\ E-mail: $\quad$ agustianiputri15@gmail.com ${ }^{1)}$ \\ dansu.sumardani@gmail.com $^{2)}$ \\ wardani.rahayu@unj.ac.id ${ }^{3)}$ \\ mimi.nurhajizah@gmail.com $^{4)}$
}

Received 15 January 2020; Received in revised form 25 March 2020; Accepted 29 March 2020

\begin{abstract}
Abstrak
Penelitian ini bertujuan untuk membandingkan kemampuan berpikir kritis matematis siswa yang belajar menggunakan model generative learning dan connecting, organizing, reflecting, extending (CORE). Metode penelitian yang digunakan adalah metode eksperimen semu yang dilakukan pada kelas XI SMA Negeri 12 Jakarta. Teknik pengambilan sampel menggunakan purposive sampling. Kemampuan berpikir kritis matematis siswa diukur dengan tes yang dibuat sesuai indikator keterampilan berpikir kritis matematis pada materi integral sebanyak 5 soal yang telah melalui uji validitas dan reliabilitas. Kedua kelas eksperimen yang dipilih berasal dari populasi yang berdistribusi normal, memiliki varians homogen dan mempunyai kesamaan rata-rata. Berdasarkan hasil penelitian, kelas eksperimen I dengan model generative learning dan kelas eksperimen II dengan model CORE berdistribusi normal dan memiliki varians yang sama. Pengujian hipotesis dilakukan dengan uji-t dan taraf signifikansi $\alpha=0,05$. Berdasarkan hasil perhitungan, diperoleh $t_{\text {hitung }}=2,554$ dan $t_{\text {tabel }}=1,667$ sehingga $t_{\text {hitung }}>t_{\text {tabel }}$, maka $H_{0}$ ditolak. Oleh karena itu, dapat disimpulkan bahwa kemampuan berpikir kritis matematis siswa yang belajar dengan model generative learning lebih tinggi daripada model CORE.
\end{abstract}

Kata kunci: CORE; generative learning; kemampuan berpikir kritis matematis.

\begin{abstract}
The objective of this study was to compare in mathematical critical thinking skills of students who learn to use the generative learning and CORE models. The research method applied is a quasi-experimental method carried out in class XI SMAN 12 Jakarta. The sampling technique in this study adopted purposive sampling. Students' mathematical critical thinking skills were measured by tests made according to indicators of mathematical critical thinking skills of the integral material as many as 5 questions that have been tested through validity and reliability. The two experimental classes selected came from populations that were normally distributed, had homogeneous variances and had similarities on average. Based on the results of the study, the experimental class I (generative learning model) and experimental class II (CORE model) were normally distributed and had the same variance. Hypothesis testing is done by using t-test statistics with a significance level $\alpha=0.05$. Based on the results of calculations, obtained $t_{\text {count }}=2.554$ dan $t_{\text {table }}=1.667$ therefore $t_{\text {count }}>t_{\text {table }}$, then $H_{0}$ is rejected. Therefore, it can be concluded that the mathematical critical thinking skill of students taught with the generative learning model is higher than the students taught using the CORE model.
\end{abstract}

Keywords: CORE; critical thinking skill; generative learning. 
DOI: https://doi.org/10.24127/ajpm.v9i1.2617

\section{PENDAHULUAN}

Matematika merupakan salah satu disiplin ilmu yang wajib dikuasai pada jenjang pendidikan dasar hingga sampai menengah. Tujuan adanya pembelajaran matematika yaitu mempersiapkan siswa agar mampu menghadapi problematika kehidupan secara logis, rasional, kritis, cermat, jujur, efisien, efektif (Suhartini \& Martyanti, 2017). Matematika tidak hanya membentuk berdaya nalar tinggi, namun juga dapat membangun sikap kritis siswa (Daniel, 2017) .

Kompetensi yang dicapai dalam pembelajaran abad 21 antara lain adalah kemampuan untuk berpikir kritis, logis, kreatif, kolaborasi, komunikasi, mampu menguasai teknologi informasi dan juga komunikasi (Muhali, 2019). Salah satu tujuan pembelajaran matematika yang harus ditingkatkan adalah kemampuan berpikir kritis agar dapat menganalisis masalah dengan baik, berpikir secara sistematis, dan mampu menyampaikan pendapat dan pengambilan keputusan yang tepat (Nugroho, 2017).

Di sekolah menengah atas, siswa diharapkan dapat mencapai kompetensi lulusan matematika yaitu berpikir kritis (Permendiknas, 2006). Hal ini kembali diungkapkan dalam kurikulum tahun 2013 bahwa mengolah dan menyajikan yang abstrak ke dalam ranah konkret terkait dengan yang dipelajarinya harus melibatkan kemampuan berpikir kritis, sehingga siswa mampu menyelesaikan masalah (Permendikbud, 2016)

Kemampuan berpikir kritis perlu ditingkatkan dalam proses pembelajaran guna memahami suatu permasalahan. Salah satu caranya yaitu menggunakan model pembelajaran yang tepat. Beberapa penelitian menyatakan bahwa kemampuan berpikir kritis rendah dapat ditingkatkan pembelajaran yang menggunakan model generative learning (Rabani, 2014). Hal ini disebabkan siswa dapat dilibatkan dalam menganalisis, mengevaluasi ideide, dan mengungkapkan alasan dengan cara menghubungkan pengetahuan yang dimiliki sebelumnya dan yang sedang dipelajarinya.

Kemampuan berpikir kritis siswa juga dapat ditingkatkan melalui model Connecting, Organizing, Reflecting, and Extending atau CORE (Asma, 2018). Hal ini terjadi disebabkan siswa dapat terlibat secara aktif pada proses berpikir kritis dengan membangun pengetahuan yang baru dari pengetahuan sebelumnya dan menemukan solusi melalui sharing ide dengan teman, mempelajari ide-ide yang berbeda, serta mengevaluasi hasil pemikiran.

Perbandingan kedua model generative learning dan CORE untuk kemampuan berpikir kritis siswa belum ada pada penelitian sebelumnya, hanya ada penelitian yang menerapkan generative learning dan CORE untuk kemampuan pemecahan masalah. Hasil penelitian tersebut menunjukkan bahwa kemampuan pemecahan masalah yang belajar menggunakan model generative learning lebih tinggi daripada dengan model CORE (Chistella \& Soekamto, 2017)

Pada kenyataannya, melatih kemampuan berpikir kritis siswa belum sepenuhnya diterapkan pada proses pembelajaran. Sekolah justru hanya mendorong siswa untuk memberi jawaban tunggal secara imitatif daripada meminta untuk memunculkan ide baru atau mengevaluasi informasi yang ada (Suwanjal, 2016). Guru lebih meminta siswa hanya membaca, mendefinisikan, mendeskripsi, dan menyatakan daripada menganalisis, dan menarik kesimpulan, menghubungkan, mengevaluasi ide-ide, mengkritik (Salsabila, Rahayu, Kharis, \& Putri, 2019). 
Rendahnya kemampuan berpikir kritis siswa SMA terhadap matematika terlihat pada UNBK 2019 yang memuat soal berpikir tingkat tinggi (Akhyar, 2019) Pada tingkat nasional, persentase daya serap tertinggi siswa SMA pada materi aljabar sebesar 45,50\%, dan persentase daya serap terendah materi kalkulus sebesar 34,59\%. Pada tingkat Provinsi Jakarta, persentase daya serap tertinggi siswa SMA pada materi aljabar sebesar 60,31\% terdapat di Kota Jakarta Pusat, sedangkan daya serap terendah pada materi kalkulus sebesar $44,80 \%$ di Kota Jakarta Timur (Tyas \& Manurung, 2018). Hal tersebut dapat diindikasikan bahwa siswa di Indonesia masih lemah berpikir kritis khususnya siswa SMA di daerah Jakarta Timur.

Salah satu SMA yang terletak di Jakarta Timur adalah SMAN 12 Jakarta. Kemampuan berpikir kritis matematis di SMA Negeri 12 Jakarta masih tergolong rendah. Hal ini ditunjukkan dari nilai siswa dari soal berpikir kritis matematis pada materi integral. Persentase semua indikator pada materi integral tidak mencapai $50 \%$. Persentase dari rata-rata total pada materi integral di SMAN 12 Jakarta sebesar 30\% lebih rendah jika dibandingkan rata-rata dari daya serap seluruh siswa SMA di Jakarta Timur sebesar $44,80 \%$.

Berdasarkan hasil observasi dari proses pembelajaran di kelas XI SMAN 12 Jakarta, terdapat faktor yang dapat menyebabkan berpikir kritis matematis siswa rendah. Salah satunya adalah guru yang jarang memberikan stimulus siswa di awal pelajaran. Guru lebih dominan memberikan rumus. Pembelajaran tidak melibatkan siswa untuk berdiskusi dan guru hanya menjelaskan materi di papan tulis, serta meminta siswa untuk menyelesaikan soal di dalam buku yang tersedia. Hal ini menyebabkan kemampuan berpikir kritis siswa tidak dapat berkembang, sehingga dibutuhkan model pembelajaran yang tepat.

Oleh karena itu, solusi untuk menyelesaikan permasalahan tersebut yaitu menerapakan proses pembelajaran menggunakan model yang tepat. Sehingga, tujuan penelitian ini adalah untuk mengetahui kemampuan berpikir kritis matematis siswa menggunakan model generative learning dan CORE pada materi kalkulus di kelas XI SMAN 12 Jakarta.

\section{METODE PENELITIAN}

Penelitian ini adalah kuantitatif yang di dalamnya terdapat analisis dan penarikan kesimpulan yang diperoleh dari hasil pengujian data. Metode yang digunakan dalam penelitian ini adalah eksperimen semu, karena penelitian ini tidak memungkinkan untuk mengontrol sepenuhnya terhadap variabel-variabel luar yang dapat mempengaruhi dalam pelaksanaan eksperimen. Desain penelitian disajikan pada Tabel 1

Tabel 1. Desain Penelitian

\begin{tabular}{ccc}
\hline Kelas & Perlakuan & Tes \\
\hline $\mathrm{E}_{1}$ & $\mathrm{X} E_{1}$ & $\mathrm{Y}$ \\
$\mathrm{E}_{2}$ & $\mathrm{X} E_{2}$ & $\mathrm{Y}$ \\
$\mathrm{E}_{3}$ & $\mathrm{XE} E_{3}$ & $\mathrm{Y}$ \\
\hline
\end{tabular}

Keterangan:

$\mathrm{E}_{1}=$ Kelas eksperimen I

$\mathrm{E}_{2}=$ Kelas eksperimen II

$\mathrm{E}_{2}=$ Kelas kontrol

$\mathrm{X} E_{1}=$ Perlakuan kelas eksperimen I

$\mathrm{X} E_{2}=$ Perlakuan kelas eksperimen II

$\mathrm{X} E_{3}=$ Konvensional

$\mathrm{Y}=$ Rata-rata tes akhir

Penelitian ini dilakukan pada siswa di SMAN 12 Jakarta kelas XI semester genap. Waktu penelitian dari 9 April - 13 Mei 2019. Jadwal penelitian 
dilaksanakan setiap hari Selasa, Rabu, dan Kamis di SMA Negeri 12 Jakarta.

Populasi penelitian ini adalah seluruh siswa kelas XI di SMA Negeri 12 Jakarta yang terdaftar pada semester genap 2018/2019. Pengambilan sampel pada penelitian ini menggunakan teknik purposive sampling. Kelas XI MIPA 1 adalah kelas eksperimen I menggunakan model generative learning berjulmah 36 orang dan kelas XI MIPA 2 sebagai kelas eksperimen II yang diterapkan model CORE berjumlah 36 orang. kelas XI MIPA 3 sebagai kelas control.

Pengamatan penelitian ini berlangsung 8 pertemuan. 7 pertemuan untuk menerapkan model pembelajaran di kelas eksperimen dan 1 pertemuan ( 2 jam pelajaran) untuk tes kemampuan berpikir kritis matematis siswa di kedua kelas setelah diterapkan model generative learning dan CORE.

Kemampuan dalam berpikir kritis matematis siswa dapat diukur melalui instrumen tes berupa 5 soal berbentuk uraian pada materi integral yang sudah disesuaikan dengan indikator berpikir kritis. Post-test ini diberikan kepada siswa untuk mengetahui kemampuan berpikir kritis matematis siswa setelah diberikan perlakuan. Sebelum instrumen digunakan, dilakukan uji validitas oleh ahli dan juga empiris, serta diujicobakan pada kelas yang bukan eksperimen.

Selanjutnya, untuk mengetahui keadaan awal kelas sebelum dijadikan sampel dilakukan uji prasyarat analisis pada ketiga kelas tersebut, yaitu uji normalitas, uji homogenitas serta uji kesamaan rata-rata menggunakan data hasil ulangan tengah semester.

Data yang diperoleh penelitian ini merupakan hasil tes kemampuan berpikir kritis matematis siswa. Hasil tes kemampuan berpikir kritis siswa diperoleh dari hasil skor tes pada dua kelas eksperimen. Tes yang diberikan pada kedua kelas eksperimen adalah sama. Tes yang digunakan berupa soal uraian untuk mengukur kemampuan berpikir kritis matematis siswa setelah diberi sebuah perlakuan yaitu penerapan model generative learning dan CORE.

Teknik analisis data dilakukan baik sebelum dan setelah perlakuan. Tahap pengujian sebelum perlakuan yaitu uji normalitas, homogenitas, dan kesamaan rata-rata. Sedangkan tahapan setelah perlakuan yaitu uji normalitas, homogenitas, dan Anova 1 arah.

Uji normalitas yang digunakan sebelum dan setelah perlakuan adalah uji Lilliefors dengan $\alpha=0,05$. Kriteria yang digunakan dalam uji ini adalah $L_{0}>L_{\text {tabel }}$ maka $H_{0}$ ditolak, berarti sampel yang digunakan pada penelitian ini berasal dari populasi yang tidak berdistribusi normal.

Uji homogenitas yang dilakukan sebelum perlakuan untuk mengetahui kelas yang berasal dari populasi yang homogen atau tidak. Sampel pada uji homogenitas berasal dari populasi yang berdistribusi normal. Uji homogenitas dilakukan dengan uji Bartlett dengan $\alpha$ $=0,05$. Kriteria dalam pengujian yaitu tolak $H_{0}$ jika $\chi^{2} \geq \chi_{(1-\alpha)(k-1)}$ dengan peluang $(1-\alpha)$ dan $d k=(k-1)$.

Uji homogenitas yang dilakukan setelah perlakuan adalah menggunakan uji Fisher dengan taraf signifikan $\alpha=0,05$. Data yang digunakan adalah hasil tes kemampuan berpikir kritis matematis siswa pada pokok bahasan integral. Uji ini tak hanya sebagai uji prasyarat, namun juga sebagai penentu statistik uji- $t$ yang digunakan untuk menguji hipotesis.

Pengujian hasil kesamaan ratarata dilakukan sebelum perlakuan untuk mengetahui kondisi awal rata-rata kelas sebelum perlakuan. Uji kesamaan ratarata dalam penelitian ini menggunakan uji analisis varians satu arah dengan $\alpha=$ 
0,05 . Kriteria dalam pengujian ini yaitu $F_{\text {hitung }}>F_{\text {tabel }}$ maka $H_{0}$ ditolak yang berarti bahwa terdapat perbedaan ratarata pada ketiga kelas. Oleh karena itu, dilakukan uji lanjutan dengan uji Tukey.

Pengujian hipotesis ini bertujuan untuk mengetahui apakah kemampuan berpikir kritis matematis menggunakan model generative learning lebih tinggi daripada menggunakan model CORE. Pengujian hipotesis ini menggunakan statistik uji $t$, dimana $\sigma_{1}^{2}=\sigma_{2}^{2}$ dengan taraf signifikan $\alpha=0,05$. Kriteria pada pengujian yang digunakan yaitu Jika $t_{\text {hitung }}>t_{\text {tabel }}$, maka $H_{0}$ ditolak.

\section{HASIL DAN PEMBAHASAN}

Hasil tes kemampuan berpikir kritis matematis siswa yang diperoleh pada pokok bahasan integral pada kelas ekperimen I dan II di kelas XI SMA Negeri 12 Jakarta yang tercantum pada Tabel 2.

Tabel 2. Statistik deskriptif hasil tes kemampuan berpikir kritis.

\begin{tabular}{lcc}
\hline Statistik & Kelas I & Kelas II \\
\hline$n$ & 36 & 36 \\
$x_{\max }$ & 100 & 93,33 \\
$x_{\min }$ & 60 & 53,33 \\
$R$ & 40 & 40 \\
$M o$ & 80 & 80 \\
$\bar{X}$ & 80,19 & 73,33 \\
$S$ & 11,43 & 11,27 \\
$Q_{1}$ & 73,33 & 66,67 \\
$Q_{2}$ & 80 & 73,33 \\
$Q_{3}$ & 86,67 & 80 \\
\hline
\end{tabular}

Pada Tabel 2, menunjukkan nilai maksimum dan minimum tes siswa pada kelas eksperimen I lebih tinggi daripada siswa kelas eksperimen II. Nilai modus dan jangkauan pada kelas eksperimen I sama dengan kelas eksperimen II. Selain itu, nilai rata-rata siswa kelas eksperimen I adalah 80,19. Nilai ini lebih tinggi jika dibandingkan dengan rata-rata pada kelas eksperimen II sebesar 73,33.

Pada Tabel 1 juga menunjukkan simpangan baku kelas eksperimen I lebih tinggi daripada kelas eksperimen II. Hal ini berarti kemampuan berpikir kritis matematis dari siswa yang belajar dengan menggunakan model generative learning lebih beragam dibandingkan siswa yang belajar menggunakan model CORE.

\section{Uji Normalitas Sebelum Perlakuan}

Uji normalitas menggunakan uji Lilliefors dengan $\alpha=0,05$. Data yang digunakan adalah nilai ulangan tengah semester matematika kelas XI MIPA 1, XI MIPA 2, dan XI MIPA 3. Kriteria yang digunakan dalam uji ini adalah $L_{0}>L_{\text {tabel }}$ maka $H_{0}$ ditolak, berarti sampel yang digunakan pada penelitian ini berasal dari populasi yang tidak berdistribusi normal. Berikut ini yang merupakan hasil pengujian normalitas ketiga kelas sebelum diberi perlakuan dengan menggunakan uji Lilliefors dapat dilihat pada Tabel 3.

Tabel 3. Perhitungan hasil uji normalitas sebelum perlakuan

\begin{tabular}{ccc}
\hline Kelas & $\boldsymbol{L}_{\mathbf{0}}$ & $\boldsymbol{L}_{\text {tabel }}$ \\
\hline XI MIPA 1 & 0,117 & 0,227 \\
XI MIPA 2 & 0,109 & 0,227 \\
XI MIPA 3 & 0,129 & 0,227 \\
\hline
\end{tabular}

Berdasarkan Tabel 3, secara keseluruhan dari ketiga kelas tersebut memiliki $L_{0}<L_{\text {tabel }}$, maka diperoleh sebuah kesimpulan bahwa ketiga kelas berdistribusi normal.

\section{Uji Homogenitas Sebelum Perlakuan}

Uji homogenitas yang dilakukan untuk mengetahui kelas berasal dari 
populasi yang homogen atau tidak. Sampel pada uji homogenitas berasal dari populasi yang telah berdistribusi normal. Uji homogenitas dilakukan menggunakan uji Bartlett dengan $\alpha=$ 0,05 . Kriteria pada pengujian yaitu tolak $H_{0} \quad$ ketika $\chi^{2} \geq \chi_{(1-\alpha)(k-1)} \quad$ dengan peluang $(1-\alpha)$ dan $d k=(k-1)$.

Berdasarkan uji homogenitas, diperoleh $\chi_{\text {hitung }}^{2}=0,065$ dan $\chi_{\text {tabel }}^{2}=$ 5,992. Dengan demikian, disimpulkan $\chi_{\text {hitung }}^{2}<\chi_{\text {tabel }}^{2}$ maka $H_{0}$ diterima atau ketiga kelas tersebut memiliki varians sama atau homogen.

\section{Uji Analisis Kesamaan Rata-rata}

Pengujian hasil kesamaan ratarata dilakukan untuk mengetahui kondisi awal rata-rata kelas sebelum perlakuan. Uji kesamaan rata-rata dalam penelitian ini menggunakan uji analisis varians satu arah dengan $\alpha=0,05$.

Berdasarkan hasil perhitungan anava, diperoleh nilai $F_{\text {hitung }}=3,571$ dan $F_{\text {tabel }}=3,079$. Dengan demikian, dapat disimpulkan bahwa $F_{\text {hitung }}>$ $F_{\text {tabel }}$ maka $H_{0}$ ditolak yang berarti bahwa terdapat perbedaan rata-rata pada ketiga kelas. Oleh karena itu, dilakukan uji lanjutan dengan uji Tukey (Tabel 4).

Tabel 4. Perhitungan Uji Lanjutan Tukey

\begin{tabular}{ccc}
\hline Kelas & $\boldsymbol{Q}_{\text {hitung }}$ & $\boldsymbol{Q}_{\text {tabel }}$ \\
\hline 1 vs 2 & 1,806 & 5,856 \\
1 vs 3 & 6,389 & 5,856 \\
2 vs 3 & 4,583 & 5,856 \\
\hline
\end{tabular}

Berdasarkan Tabel 4, dapat terlihat bahwa terdapat dua pasang kelas yang tidak memiliki perbedaan rata-rata yaitu kelas XI MIPA 1 dan XI MIPA 2, serta kelas XI MIPA 2 dan MIPA 3. Selain itu, terdapat satu pasang kelas yang memiliki perbedaan rata-rata yaitu kelas XI MIPA 1 dan XI MIPA 3.

\section{Uji Normalitas Setelah Perlakuan}

Uji normalitas setelah perlakuan menggunakan uji Lilliefors dengan taraf signifikannya $\alpha=0,05$. Data yang digunakan adalah hasil tes kemampuan berpikir kritis matematis siswa kedua kelas eksperimen pada pokok bahasan integral. Kriteria yang digunakan uji ini adalah $L_{0}>L_{\text {tabel }}$ maka $H_{0}$ ditolak, berarti sampel yang digunakan dalam penelitian ini berasal dari populasi yang tidak berdistribusi normal. Berikut ini merupakan hasil pengujian normalitas kedua kelas setelah diberikan perlakuan dengan menggunakan uji Lilliefors dapat dilihat pada Tabel 5.

Tabel 5. Perhitungan hasil uji normalitas setelah perlakuan.

\begin{tabular}{ccc}
\hline Kelas & $\boldsymbol{L}_{\mathbf{0}}$ & $\boldsymbol{L}_{\text {tabel }}$ \\
\hline XI MIPA 1 & 0,118 & 0,227 \\
XI MIPA 2 & 0,139 & 0,227 \\
\hline
\end{tabular}

Berdasarkan perhitungan pada Tabel 5, diketahui bahwa kedua kelas memiliki perhitungan $L_{0}<L_{\text {tabel }}$, keputusannya $H_{0}$ diterima. Hal ini dapat disimpulkan bahwa kelas XI MIPA 1 yaitu kelas eksperimen I dan kelas XI MIPA 2 yang merupakan kelas eksperimen II berasal dari populasi yang berdistribusi normal.

\section{Uji Homogenitas Setelah Perlakuan}

Uji homogenitas menggunakan model CORE dengan uji Fisher dengan taraf signifikan $\alpha=0,05$. Data yang digunakan adalah hasil tes kemampuan berpikir kritis matematis siswa pada pokok bahasan integral. Uji ini tidak hanya sebagai uji prasyarat, namun juga digunakan sebagai penentu statistik uji- $t$ mana yang akan digunakan.

Berdasarkan dari hasil pengujian homogenitas diperoleh yaitu $0.510 \leq$ $1.040 \leq 1.961$, maka $H_{0}$ diterima. Oleh 
karena itu, disimpulkan bahwa data dari hasil tes kemampuan berpikir kritis matematis siswa di kelas eksperimen I dan juga kelas eksperimen II memiliki varians yang sama. Selanjutnya untuk menguji hipotesis menggunakan uji-t.

\section{Pengujian Hipotesis}

Pengujian hipotesis bertujuan untuk mengetahui apakah kemampuan berpikir kritis matematis siswa yang belajar menggunakan model generative learning lebih tinggi daripada siswa yang belajar dengan menggunakan model CORE. Pengujian hipotesis ini dilakukan menggunakan statistik uji- $t$ dimana $\sigma_{1}^{2}=\sigma_{2}^{2}$ dengan taraf signifikan $\alpha=0,05$. Berdasarkan hasil nilai yang diperoleh $t_{\text {hitung }}=2,554$ dan $t_{\text {tabel }}=$ 1,667. Hal ini menyatakan bahwa $t_{\text {hitung }}>t_{\text {tabel }}$, artinya $H_{0}$ ditolak.

Model yang lebih unggul secara keseluruhan adalah generative learning. Hal ini karena konsep baru diberikan ke siswa setelah siswa membuat hipotesis masalahnya. Pada model ini, terdapat penguatan konsep dari guru setelah siswa memaparkan hasil diskusi. Hal ini membuat siswa termotivasi membangun kemampuan berpikir kritis matematis yang lebih optimal.

Model CORE memiliki dampak yang lebih rendah karena konsep baru diberikan sebelum siswa menghadapi dan membuat hipotesis masalah terlebih dahulu. Selain itu, guru tidak memberi penguatan pada akhir pelajaran setelah pembahasan, sehingga siswa kehilangan antusiasmenya dalam diskusi kelompok.

Pembelajaran model generative learning di kelas diawali dengan siswa mengeksplor konsep baru menggunakan pengetahuan yang telah dipelajari secara berkelompok. Siswa juga dituntut untuk mengemukakan gagasan dan beberapa pertanyaan untuk menggali informasi yang dikembangkan menjadi hipotesis.
Kegiatan menghubungkan konsep atau prinsip yang lama dengan yang baru ini dapat mengembangkan kemampuan berpikir kritis matematis.

Setelah itu, siswa juga diarahkan fokus terhadap masalah yang disajikan dan memilih strategi yang tepat untuk menyelesaikan masalah dan mengaitkan konsep yang telah diperoleh. Siswa juga dituntut memilih data yang relevan yang dapat digunakan untuk menyelesaikan masalah yang berkaitan dengan materi baru. Siswa juga memeriksa kebenaran informasi yang telah diperoleh agar sesuai dengan hasil perhitungan. Pada tahap ini, siswa mampu meningkatkan kemampuan berpikir kritis.

Selanjutnya, guru juga meminta siswa untuk mempresentasikan hasil diskusi kelompoknya di depan kelas. Guru hanya mengawasi kondisi agar tidak keluar dari pembahasan materi. Setelah itu, guru memberikan penguatan dengan memeriksa konsep baru yang ditemukan oleh siswanya. Pada tahap ini, siswa menguji keabsahan konsep untuk diaplikasikan. Kegiatan ini dapat berupa menghubungkan, menganalisis, mengevaluasi. Dengan demikian, pada tahap ini kemampuan berpikir kritis matematis siswa dapat meningkat.

Situasi ini berbeda dengan kelas yang menggunakan model pembelajaran CORE. Tahapan pembelajaran model CORE diawali dengan menghubungkan konsep yang lama dengan konsep yang baru. Guru menjelaskan konsep yang akan dipelajari, sehingga siswa mampu memahami konsep yang baru sebelum berdiskusi membahas LKPD.

Selanjutnya, siswa mengerjakan LKPD tersebut secara berkelompok yang telah ditentukan kelompoknya. Siswa harus mengidentifikasi informasi yang relevan dan tidak relevan untuk menyelesaikan masalah. Kegiatan ini juga meningkatkan kemampuan berpikir 
kritis siswa. Kemudian guru meminta salah satu kelompok presentasi hasil diskusinya di depan kelas. Siswa memeriksa pengetahuan dan kebenaran justifikasi. Siswa dapat melihat kembali kesimpulan dengan mempertimbangkan argumentasi dari hasil diskusi kelompok lainnya, serta memperbaiki kesalahan yang mungkin terjadi. Kemudian, siswa menyelesaikan masalah yang kompleks, berkaitan dengan berbagai topik.

Berdasarkan hasil analisis dan pembahasan, model generative learning lebih unggul dalam proses dan tahap pembelajarannya dibandingkan dengan model CORE. Selain itu, dari hasil uji statistik juga menunjukkan kemampuan berpikir kritis matematis siswa yang belajar dengan model generative learning lebih tinggi dibandingkan siswa yang belajar dengan menggunakan model CORE.

Model generative learning memberikan konsep baru pada siswa setelah siswa membuat hipotesis masalahnya. Selain itu, model ini terdapat penguatan konsep. Hal ini yang membuat siswa dapat termotivasi untuk membangun kemampuan berpikir kritis. Sedangkan, pada model CORE memiliki dampak yang lebih rendah karena konsep baru diberikan sebelum siswa menghadapi dan juga membuat hipotesis masalah. Hal ini menyebabkan siswa dapat kehilangan antusiasme dalam diskusi kelompok.

Hasil penelitian ini juga sejalan dengan penelitian yang menyatakan bahwa model generative learning memberikan proses yang sangat aktif bagi siswa sehingga menciptakan berpikir kritis sendiri dengan menghubungkan konsep yang telah mereka miliki (Simanjuntak \& Suharyati, 2018) Sedangkan menurut Calfee, model pembelajaran CORE menuntut siswa untuk belajar aktif dan mendorong siswa untuk dapat berpikir kritis bersama siswa lainnya dengan menemukan kekeliruan dan membentuk menjadi pengetahuan yang baru (Asma, Siregar, \& Hakim, 2018).

Penelitian lain yang mendukung penelitian ini juga menyatakan bahwa kemampuan berpikir kritis matematis dengan menggunakan model generative learning meningkat (Rabani, 2014). Hal ini disebabkan siswa dapat dilibatkan dalam menganalisis, mengevaluasi ideide, dan mengungkapkan alasan.Selain itu, model CORE dapat meningkatkan kemampuan bepikir kritis dengan aktif membangun pengetahuan yang baru dari pengetahuan sebelumnya melalui sharing ide dengan teman, mempelajari ide yang berbeda, serta mengevaluasi hasil pemikiran (Putri \& Arifin, 2017).

Perbandingan kedua model dapat sejalan dengan penelitian sebelumnya, menyatakan model generative learning lebih baik dampaknya pada kemampuan pemecahan masalah dari model CORE (Chistella \& Soekamto, 2017).

\section{KESIMPULAN DAN SARAN}

Berdasarkan hasil penelitian dan pembahasan dapat disimpulkan bahwa terdapat perbedaan kemampuan berpikir kritis matematis antara siswa yang belajar menggunakan model generative learning dan CORE materi integral kelas XI di SMA Negeri 12 Jakarta. Kemampuan berpikir kritis matematis yang menggunakan model generative learning lebih tinggi daripada siswa yang belajar dengan model CORE.

Berkenaan hasil penelitian yang diperoleh, maka saran untuk penelitian berikutnya adalah menggunakan model generative learning dan model CORE pada tingkat kelas dan pokok bahasan berbeda. Selain itu, dalam pelaksaannya hendak memperhatikan setiap tahapan kedua model tersebut. 


\section{DAFTAR PUSTAKA}

Akhyar, M. K. (2019). Analisis HOTS pada Soal UNBK Terhadap Hasil UN Matematika SMA di Indonesia. Jurnal Faktor M, 1(2), 143-159.

Asma, N. (2018). Pengaruh Model CORE terhadap Kemampuan Berpikir Kritis dan Disposisi Matematis Ditinjau dari Kemampuan Awal Matematika Siswa SMA Negeri di Jakarta Timur. JJPM, 11(1), 187-196.

Asma, N., Siregar, R., \& Hakim, L. E. (2018). Pengaruh Model Pembelajaran CORE Terhadap Kemampuan Berpikir Kritis dan Disposisi Matematis Ditinjau dari Kemampuan Awal Matematika Siswa SMA Negeri di Jakarta Timur. JJPM, 11(1), 187-196.

Chistella, C., \& Soekamto, H. (2017). A Comparison between Generative Learning Model and CORE Learning Model: The Influence on Learners' Higher Order Thinking Skill. IOSR Journal of Research \& Method in Education, 07(02), 4852.

Daniel, F. (2017). Kemampuan Berpikir Kritis Siswa Pada Implementasi Project Based Learning (PJBL) Berpendekatan Saintifik. JPMI (Jurnal Pendidikan Matematika Indonesia), 1(1), 7.

Muhali. (2019). Pembelajaran Inovatif Abad Ke-21. Jurnal Penelitian dan Pengkajian Ilmu Pendidikan: ESaintika, 3(2), 25-50.

Nugroho, P. B. (2017). Scaffolding Meningkatkan Berpikir Kritis Pembelajaran Matematika. Jurnal Silogisme: Kajian Ilmu Matematika dan Pembelajarannya, 2(1), 15-21.

Permendikbud. (2016). Peraturan Menteri Pendidikan Dan
Kebudayaan Nomor 24 Tahun 2016 Tentang Kompetensi Inti Dan Kompetensi Dasar Pelajaran Pada Kurikulum 2013 Pada Pendidikan Dasar dan Pendidikan Menengah. Jakarta.

Permendiknas. (2006). Peraturan Menteri Pendidikan Nasional No.

23 Tahun 2006 tentang Tujuan Pendidikan. Jakarta

Putri, M. D., \& Arifin, R. R. M. (2017). Pengaruh Penerapan Model CORE (Connecting, Organizing, Reflecting, Extending) Terhadap Kemampuan Berpikir Kritis Matematis Siswa Sekolah Dasar. Antologi UPI, 5(1), 111-123.

Rabani. (2014). Perbedaan Kemampuan Berpikir Kritis Matematis Siswa SMP yang Diajar dengan Model Pembelajaran Generatif dan Pembelajaran Langsung. Jurnal Penelitian Pendidikan Matematika, 2(3), 77-88.

Salsabila, E., Rahayu, W., Kharis, S. A., \& Putri, A. (2019). Analysis of Mathematical Literacy on Students' Metacognition in Conic Section Material. Journal of Physics: Conference Series, 1417(1), 1-8.

Simanjuntak, P., \& Suharyati. (2018). Pengaruh Model Pembelajaran Generatif Terhadap Kemampuan Berpikir Kritis Matematis Siswa. Gamaedu, 3(4), 52-61.

Suhartini, S., \& Martyanti, A. (2017). Kemampuan Berpikir Kritis pada Pembelajaran Geometri Berbasis Etnomatematika. Jurnal Gantang, 2(2), 105-111.

Suwanjal, A. (2016). Pengaruh Penerapan Pendekatan Kontekstual Terhadap Kemampuan Berpikir Kritis Matematis Siswa SMP. Jurnal Aksioma, 5(1), 61-67. 
DOI: https://doi.org/10.24127/ajpm.v9i1.2617

Tyas, D. K. F. N., \& Manurung, M. M.

H. (2018). Penguasaan Materi

Matematika SMU Mahasiswa

Semester 1 Program Studi

Pendidikan Matematika. Jurnal

Ilmiah Mandala Education, 4(1), 105-109. 